\title{
FOREIGNERS IN RUSSIA
}

DOI: $10.15826 /$ qr.2015.1.078

УДК 355.081(470) (091) + 316.343

Сергей Черников

\author{
РОССИЙСКИЙ ГЕНЕРАЛИТЕТ 1730-1741 гГ.: \\ ЧИСЛЕННОСТЬ, НАЦИОНАЛЬНЫЙ И СОЦИАЛЬНЫЙ \\ СОСТАВ, ТЕНДЕНЦИИ РАЗВИТИЯ ${ }^{1}$
}

\section{Sergey Chernikov}

\section{RUSSIAN GENERALS BETWEEN 1730 AND 1741: NUMBERS, NATIONAL AND SOCIAL BACKGROUND, TRENDS}

Referring to a vast number of archival and published sources, the author analyzes the social structure and development tendencies of the Russian General Officers between 1730 and 1741. The growth in the numbers of generals under Anna Ioannovna had ceased in the period in question. As opposed to the five previous years, the numbers of generals between 1730 and 1741 were directly conditioned by whether the army was involved in military activities. After the confirmation of the new staff in 1731, the number of generals decreased reaching 104-108 persons, while during the Russo-Turkish and Swedish wars, it increased to 113-129 persons. The structure of the general officers' staff between 1730 and 1741 reflected the overall changes in the armed forces of the time. The number of generals in the field army was decreasing, while it remained unchanged in the military units financed by sources other than chevage (artillery, engineer corps, land militia, defence forces). According to the general data, between 1730 and 1738, 60 to 63 percent of the generals were Russian nationals, and 37 to 40 percent non-Russian nationals. Consequently, after Anna Ioannovna was enthroned, there were no significant changes in the general officers' national structure. It was only at the very end of the period that due to a mass resignation of Russian generals, the numbers of foreign general officers grew: in 1739 they accounted for 42 percent, and between 1740 and 1741 - for 45-46 percent. In the field army, the growth of the number of

${ }^{1}$ Исследование выполнено при финансовой поддержке РГНФ, проект № 14-0100011(a).

() Черников С., 2015

Quaestio Rossica • 2015 • №1, p. 39-58 
non-Russian nationals continued with 35 percent in $1725,42-45$ percent in 1726-1730, and as many as 51-70 percent in 1739-1741. Foreign general officers prevailed, as previously, in the artillery and engineer corps with Russian generals employed in the military administration. The land militia forces were commanded by non-Russian generals. According to the general data between 1730 and 1741, equally to the preceding five years, the majority of foreign generals were from Germany (43 to 45 percent). Having started under Peter I, the incorporation of the Baltic nobility into Russian elite continued, while the numbers of Baltic Germans among the generals considerably increased (from 10 to 28 percent). Non-Russian generals taking service between 1730 and 1741, as a rule, had military experience and were assigned to the field army and land militia. The renewal of the command of the artillery, engineer and defence forces, as well as the military administration was mainly carried out by means of promoting the officers that were already serving in the Russian military forces. The development of the social structure of the Russian part of general officers remained unaltered. The amount of the traditional elite decreased from 40-43 percent in 1730-1731 to 34-35 percent in 1740-1741. After three decades since the start of the military reforms of Peter the Great, representatives of the Moscow nobility were promoted to generals in chief and accounted to the majority of such positions. It was only the senior rank of field marshals that was made up of the nobility. Overall, the development of the general officials' corps between 1730 and 1741 followed the general pattern of the development of Russian military forces initiated under Peter the Great, and the changes of the beginning of Anna Ioannovna's reign were the result of the internal policy that was formulated by the reformer-tsar's associates between 1725 and 1727 .

Keywords: general officers; ruling elite; army; military service; national composition; social composition.

В статье на основании широкого круга архивных и опубликованных источников анализируются состав, социальная структура и динамика российского генералитета 1730-1741 гг. Расширение генеральского корпуса, которое наблюдалось в 1725-1730 гг., при Анне Иоанновне прекратилось. В отличие от предшествующих пяти лет, численность генералитета 1730-1741 гг. напрямую зависела от того, вела ли армия боевые действия. После утверждения в 1731 г. нового штата число генералов снизилось до 104-108 человек, а в период турецкой и шведской войн вновь увеличилось до 113-129 лиц. Структура генералитета 1730-1741 гг. отражала общие изменения в вооруженных силах того времени. Доля генералитета при полевой армии снижалась. В тех же частях, которые финансировались из источников вне подушной подати (артиллерия, инженерный корпус, ландмилиция, гарнизонные войска), такой тенденции не наблюдалось. По общим данным, среди генералов 1730-1738 гг. насчитывалось 60-63 \% 
русских и 37-40 \% иноземцев, что соответствовало показателям 1725-1730 гг. Таким образом, после восшествия на престол Анны Иоанновны резких изменений в национальном составе генералитета не произошло. Лишь в самом конце периода из-за массовых отставок русских генералов доля иноземцев выросла: в 1739 г. - 42 \%, а в 1740-1741 гг. - 45-46 \%. В полевой армии рост числа иноземцев продолжился: в 1725 г. - 35 \%, в 1726-1730 гг. - 42-45 \%, в 1730-1738 гг. 46-50 \%, в 1739-1741 гг. - 51-70\%. В артиллерии, инженерном корпусе, как и ранее, доминировали иноземные генералы, а в военной администрации - русские. Командование ландмилиции в основном состояло из иноземцев. По общим данным в 1730-1741 гг. (как и в предшествующие пять лет) среди иноземцев преобладали выходцы из Германии 43-45 \%. Начавшаяся еще при Петре I инкорпорация представителей прибалтийского дворянства в состав российской элиты продолжилась, а доля остзейцев в генералитете существенно выросла - с 10 до 28 \%. Иноземные генералы, поступившие на службу в 1730-1741 гг., как правило, имели европейский военный опыт и в основном направлялись в полевую армию и ландмилицию. Обновление командования артиллерийских, инженерных, гарнизонных частей и военной администрации осуществлялось в первую очередь за счет повышения в чинах тех, кто уже находился на российской службе. Динамика социальной структуры русской части генералитета осталась прежней. Доля традиционной элиты снизилась с 40-43 \% в 1730-1731 гг. до 34-35 \% в 1740-1741 гг. Спустя три десятилетия после начала петровских военных реформ представители московского дворянства достигли чина генерал-аншефа и составили в нем большинство. Аристократическим остался лишь старший - фельдмаршальский - класс. В целом эволюция генеральского корпуса 1730-1741 гг. подчинялась общей логике развития вооруженных сил России, заложенной еще при Петре Великом, а перемены начала аннинского царствования во многом стали следствием того внутриполитического курса, который был сформулирован ближайшим окружением царя-реформатора в $1725-1727$ гг.

Ключевые слова: генералитет, правящая элита, армия, служба, национальный состав, социальный состав.

Эволюция командного состава российских вооруженных сил в эпоху становления и развития регулярной армии неизменно привлекает внимание историков. Но в отличие от офицерского корпуса этого времени, подробно изученного в работах М. Д. Рабиновича и Г. В. Калашникова [Рабинович; Калашников], генералитет 1730-1741 гг. ранее не становился предметом специального исследования. В литературе до сих пор отсутствуют полные данные о его составе, социальной структуре и динамике. Вследствие этого 
выводы историков об эволюции генералитета (как и правящей элиты в целом) базируются на неполных и отрывочных сведениях, а тщательный анализ проблемы зачастую подменяется поверхностными рассуждениями о «бироновщине» и «засилии иноземцев» ${ }^{2}$. Представленная работа, основанная на широком круге архивных и опубликованных источников ${ }^{3}$, призвана восполнить указанный пробел.

\section{Численность генералитета и распределение по видам службы}

По моим подсчетам, общая численность российской элиты, носившей в 1730-1741 гг. армейские генеральские чины, составляла 266 человек ${ }^{4}$ Ежегодные показатели представлены в табл. 1.

Таблиияа 1

Численность генералитета (1730-1741 гг.)

\begin{tabular}{|l|l|l|l|l|l|l|l|l|l|l|l|l|l|l|}
\hline Год & 1730 & 1731 & 1732 & 1733 & 1734 & 1735 & 1736 & 1737 & 1738 & 1739 & 1740 А & 17405 & 1740 АЛ & 1741 \\
\hline $\begin{array}{c}\text { Число } \\
\text { лиц }\end{array}$ & 120 & 118 & 108 & 104 & 110 & 113 & 115 & 115 & 122 & 126 & 126 & 115 & 111 & 129 \\
\hline
\end{tabular}

В этой и последующих таблицах заглавными буквами после 1740 г. обозначены: время царствования Анны Иоанновны (1740А), периоды регентства Э.-И. Бирона (1740Б) и Анны Леопольдовны (1740АЛ).

\footnotetext{
${ }^{2}$ Крупными вехами на пути осмысления аннинской эпохи (как и периода «дворцовых переворотов» в целом) в последнее время стали фундаментальные работы: [Анисимов; Каменский; Курукин; Петрухинцев, 2001; Петрухинцев, 2014].

${ }^{3}$ В работе использовалась пополняемая биографическая база данных по правящей элите 1725-1762 гг. (к настоящему времени содержит более 100 тыс. записей). Основные источники: [РГАДА, ф. 16, оп. 1, кн. 20 (ч. 1-9), 36, 38, 81, 101, 134 (ч. 1-5), $135,140,141,168$ (ч. 7), 223; ф. 20 , оп. 1 , кн. 16 (ч. 1-2), 20, 21 (ч. 1-2), 50 (ч. 1-3), 61, $70-73,75,79$ (ч. 1-2), 151, 219 (ч. 1); ф. 188, оп. 1, кн. 1389; ф. 199, портф. 240, д. 15-16; ф. 210 , оп. 21, кн. 1087; оп. 22, кн. 209; ф. 248, кн. 21, 33, 46, 380, 387, 391, 394, 413, 421, $424,428,432,437,439,440,442,455,464,467,528,605,606,608,634,633,689,768,985$, 1088, 1090, 1097, 1107, 1109, 1110, 1121, 1142, 1155, 1353, 1899-1905, 1933-1942, 1947 , 1950-1952, 6416, 8122 (ч. 1-3); ф. 286, оп. 1, кн. 7, 9, 14, 17, 19, 32, 38, 39, 45, 49, 61, $63,74,75,82,84,93,106,108,117,119,122,125,131,133,139,143,145,148,160,167$, $170,181,182,208,215,216,222,228,231,238,239,245,260,262,271,273,310,331,418$ (ч. 1-2), 419, 421, 424 (ч. 1-2), 438-440, 442, 446; оп. 2, кн. 6; ф. 350, оп. 3, кн. 1; РГВИА, ф. 489, оп. 1 , кн. 7006, 7007, 7010, 7122, 7134, 7339, 7386-7388, 7391, 7395; ф. 490, оп. 2 , кн. $6-8,11,13,19-21,25,28,33-35,37,38,40-42,44,45,47,50-53,55,56,58$; оп. 3 , кн. 1, 4, 45, 46, 205-210; ф. 846, оп. 16, д. 81 (ч. 2); Сб. РИО, т. 55, 56, 63, 69, 79, 84, 94 , $101,104,106,108,111,114,117,120,124,126,130,138,146$; CA, т. 2-5].

${ }^{4}$ Под термином «генералитет» в работе понимается группа лиц, носивших армейские чины 1-5 классов Табели о рангах. Отставники и генералы, находившиеся «не у дел», при подсчетах не учитывались.
} 
С конца царствования Петра Великого до 1728-1729 гг. российский генералитет вырос в два раза - с 61 до 125-124 человек ${ }^{5}$. В 1730-1741 гг. столь резких изменений уже не наблюдалось. За первые четыре года правления Анны Иоанновны (1730-1733 гг.) количество генералов уменьшилось со 120 до 104 человек. Это объясняется тем, что в октябре 1731 г. была принята новая воинская Табель, по которой штатный состав армейского генералитета сократился с 38 до 26 лиц. Кроме того, в указанное время Россия не вела активных боевых действий (напряженность сохранялась только в Закавказье, где размещался Низовой корпус). Дальнейшие события, а именно участие России в войнах за польское наследство 1733-1735 гг. и русско-турецкой 1735-1739 гг., привели к росту генералитета. В 1739 - начале 1740 г. он насчитывал 126 человек. Сразу по завершении войны с Турцией численность генералов вследствие отставок вновь снизилась - до 115-111 лиц (конец 1740 г.), а вступление России в войну со Швецией привело к обратному эффекту - 129 лиц (1741 г.). В целом обладатели генеральских чинов составляли 49-55 \% от численности элиты 1730-1741 гг.

Очевидно, что развитие генеральского корпуса аннинского времени значительно отличалось от предшествующего периода: резкий рост в 1725-1730 гг. и сравнительно умеренные колебания в 1730-1741 гг. Но различия были не только количественными. Как было показано в моих предыдущих работах, двукратный рост генералитета при Екатерине I и Петре II был вызван целым рядом причин: ускоренной ротацией кадров в полевой армии, появлением значительной группы генералов, состоявших на статской службе, формированием новой чиновной иерархии на основе Табели о рангах, регламентацией состава различных управленческих структур (высшего армейского командования, руководства центральных и местных органов власти, двора). Напротив, динамика 1730-1741 гг. объяснялась причинами военного характера: число генералов в период войн росло, а в мирное время сокращалось.

Вполне ожидаемо, что интенсивность чинопроизводства в 1730-1741 гг. была гораздо ниже, нежели в 1725-1730 гг.: в среднем за год 19 пожалований против 35. В общей сложности за неполные 12 лет правления Анны Иоанновны и Иоанна Антоновича состоялось 232 пожалования генеральских чинов ${ }^{6}$.

Теперь обратимся к структуре генералитета 1730-1741 гг. и рассмотрим, как он распределялся по видам службы (табл. 2).

${ }^{5}$ Здесь и далее по статье сведения о генералитете 1725-1730 гг. заимствованы из моей более ранней работы [Черников, 2013а]. Отдельные незначительные расхождения с ранее опубликованными цифровыми данными по 1725-1730 гг. объясняются расширением биографической базы. Все ранее сделанные выводы подтверждаются. См. также: [Черников, 2013b; 2014a; 2014b].

${ }^{6}$ Без учета тех случаев, когда при пожаловании представитель генералитета получал полную отставку («от службы и от дел»). В 1730 г. состоялось 34 пожалования, в 1731 г. -13 , в 1732 г. -9 , в 1733 г. - 6, в 1734 г. -18 , в 1735 г. - 7, в 1736 г. - 10, в 1737 г. -28 , в 1738 г. - 13, в 1739 г. -23 , в 1740 г. -51 , в 1741 г. -20 . Повышения 1740 г. распределялись следующим образом: при Анне Иоанновне - 29, при Бироне - 15, при Анне Леопольдовне - 7. 


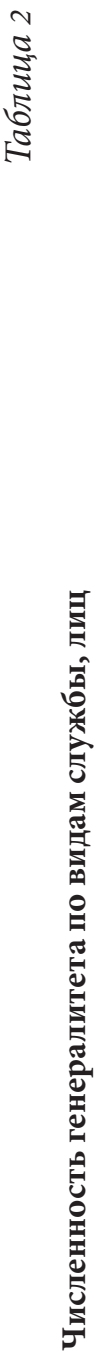

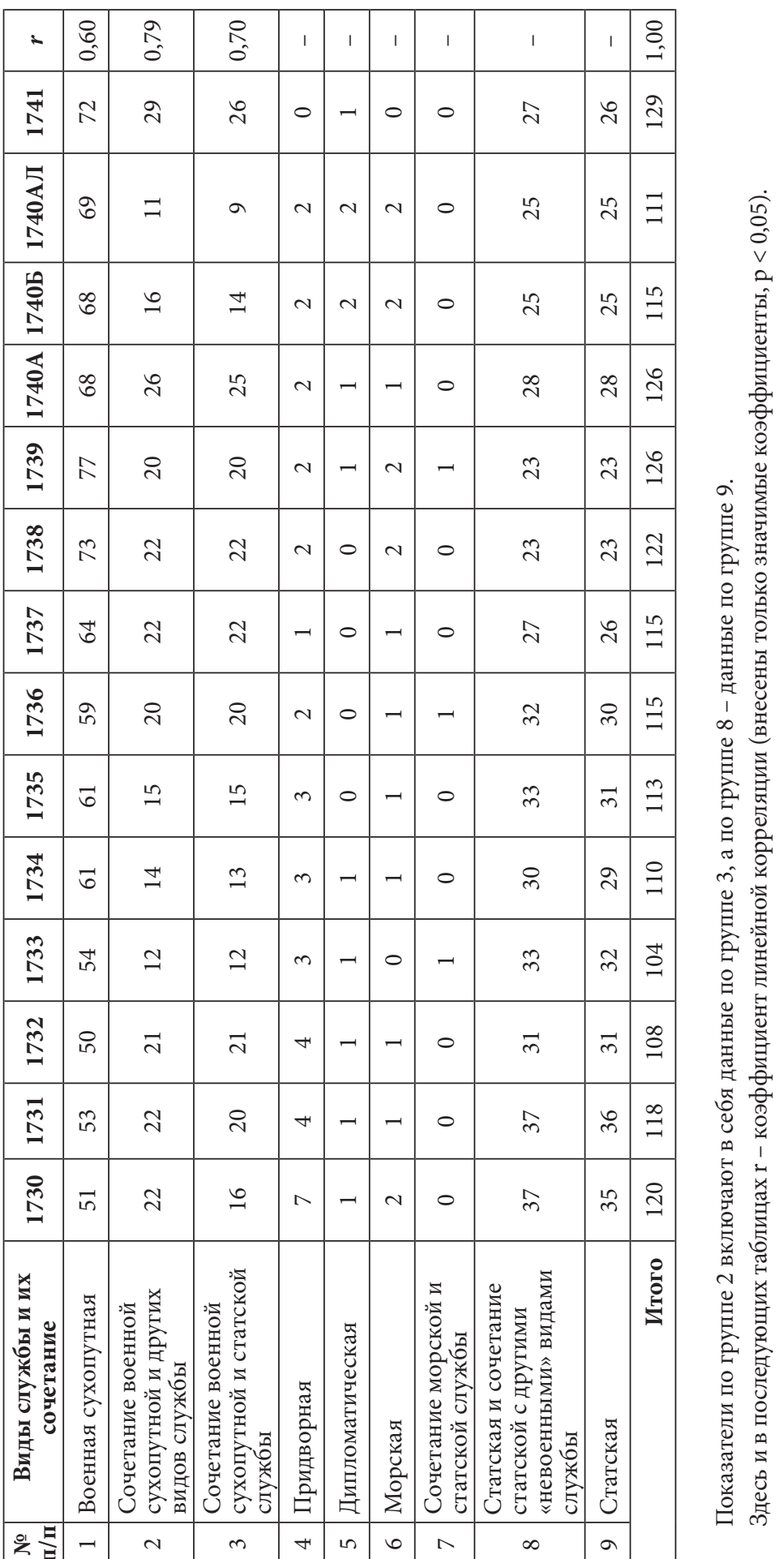


Коэффициенты корреляции, приведенные в последнем столбце, показывают, что основное влияние на общую динамику генеральских чинов оказывали военнослужащие (группа $1 ; r=0,60)$, а также лица, сочетавшие военную службу с другими видами деятельности (группы $2-3 ; r=0,70-0,79)$.

Проанализируем изменения в среде военнослужащих (группа 1). При Петре II эту категорию составляли 58-69 человек, а уже в начале правления Анны Иоанновны она сократилась до 50-54 человек. Подчеркнем, что в 1730-1741 гг. численность этой группы (в отличие от 1725-1730 гг.) напрямую зависела от того, вела ли армия боевые действия. Самые низкие показатели относятся к мирным 1730-1733 гг., а наиболее высокие - к военным 1734-1741 гг. (до 73-77 человек). Временное снижение произошло только в 1740 г., между турецкой и шведской войнами. Описанная динамика была свойственна как для иноземной, так и для русской части генералитета. Количество генералов, сочетавших военную с другими видами службы (группа 2), выросло: при Петре II их было 9-14 человек, а в 1730-1741 гг. - 11-29.

Генералитет, состоявший при гражданских делах (группа 8), постепенно сокращался: в 1728-1731 гг. - 34-38, а в 1740-1741 гг. 25-28 человек ${ }^{7}$. Но даже к концу изучаемого периода «гражданские служащие» продолжали составлять существенную часть военных чинов. Поскольку снижение численности генералов, задействованных в гражданской сфере, началось уже в 1732 г., то выявленная тенденция не была связана с известным указом 14 ноября 1735 г. о «статских повышениях» [Сб. РИО, т. 130, с. 265-266; т. 138, с. 392; CA, т. 4 , с. 338]. Также обратим внимание, что уменьшение группы 8 произошло в первую очередь за счет русских (в 1730-1731 гг. - 28-29, в 1740-1741 гг. - 19-21 человек), а генералы-иноземцы вообще редко привлекались к невоенным видам деятельности (1730-1731 гг. 8-9, 1740-1741 гг. - 6-8 человек). Еще одним важным процессом в 1730-1741 гг. стало сокращение числа придворных в генеральских рангах (группа 4).

Также интересны данные, характеризующие мобильность генералитета. За 1725-1730 гг. около 70 \% генеральского корпуса ни разу не сменили профиль службы (военный или гражданский). При Анне Иоанновне и Иоанне Антоновиче эта тенденция сохранилась: в 17301735 гг. таких было 69 \%, а в 1736-1741 гг. - 66 \%. На армейской службе постоянно находилось по периодам соответственно - 39, 37 и 44 \%, на гражданской - 31, 32 и 23 \% генералов. Вполне предсказуемо, что рост «армейской» части генералитета за счет «гражданской» совпал с военным временем.

В табл. 3 показана динамика шести основных групп, состоявших на армейской службе (группы 1-2 из табл. 2).

\footnotetext{
${ }^{7}$ Между численностью генералитета на военной службе (группа 1) и у гражданских дел (группа 8) прослеживается устойчивая обратная взаимосвязь: коэффициент корреляции между рядами данных равен $(-0,89)$.
} 


\begin{tabular}{|c|c|c|c|c|c|c|c|}
\hline- & $\begin{array}{l}\infty \\
0 \\
0 \\
0\end{array}$ & $\begin{array}{l}\hat{L} \\
\hat{n} \\
0\end{array}$ & $\begin{array}{l}\hat{0} \\
0\end{array}$ & $\overrightarrow{\hat{0}}$ & 1 & $\begin{array}{l}\mathscr{O} \\
\infty \\
0\end{array}$ & 8 \\
\hline$\underset{乛}{\stackrel{7}{2}}$ & $\mathscr{F}$ & $\stackrel{10}{\longrightarrow}$ & 0 & i్ & $\tilde{\sim}$ & $\stackrel{n}{\sim}$ & 흐 \\
\hline \begin{tabular}{l} 
\\
\multirow{2}{L}{} \\
早 \\
I
\end{tabular} & $\stackrel{\infty}{\sim}$ & $\stackrel{n}{\sim}$ & $H$ & 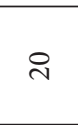 & 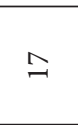 & $\simeq$ & $\infty$ \\
\hline 足 & $\tilde{m}$ & $\stackrel{\sim}{\simeq}$ & 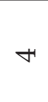 & 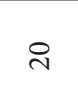 & $\triangle$ & $\simeq$ & హు \\
\hline 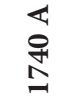 & ले & $\stackrel{m}{\sim}$ & $m$ & $\stackrel{H}{\sim}$ & $\widetilde{\sim}$ & $\stackrel{m}{\longrightarrow}$ & హ゙ \\
\hline હે & $\mathscr{F}$ & $\stackrel{\bullet}{-1}$ & 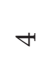 & $\stackrel{H}{\sim}$ & 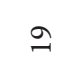 & 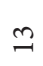 & ล̆ \\
\hline$\stackrel{\infty}{\Omega}$ & $\mathscr{F}$ & $\stackrel{0}{-1}$ & in & $\stackrel{\sim}{\sim}$ & $\stackrel{10}{-}$ & 으 & ณn \\
\hline$\hat{~}$ & $\mathcal{F}$ & 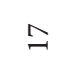 & 0 & $\curvearrowright$ & $\Xi$ & $\infty$ & $\infty$ \\
\hline$\stackrel{0}{N}$ & mे & $\triangleq$ & + & $\ddot{\sim}$ & $\stackrel{\simeq}{\simeq}$ & $a$ & 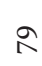 \\
\hline$\stackrel{10}{\Omega}$ & $\tilde{m}$ & $\stackrel{2}{=}$ & $\sim$ & $\curvearrowright$ & $\stackrel{0}{-1}$ & $\wedge$ & $\stackrel{6}{\wedge}$ \\
\hline$\stackrel{H}{N}$ & $\hat{m}$ & $\Xi$ & $m$ & $\curvearrowright$ & $\stackrel{0}{-1}$ & $\Lambda$ & $\stackrel{n}{N}$ \\
\hline 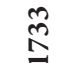 & లి & $\exists$ & $m$ & $\curvearrowright$ & $\stackrel{10}{=}$ & in & 8 \\
\hline$\stackrel{\widetilde{\Omega}}{\Omega}$ & లి & $\stackrel{\sim}{\sim}$ & $m$ & $\tilde{\sim}$ & 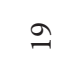 & 6 & $\nabla$ \\
\hline 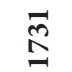 & ले & 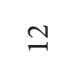 & $m$ & ป & $\stackrel{2}{二}$ & $\infty$ & $\stackrel{10}{N}$ \\
\hline 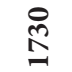 & F & $\simeq$ & 0 & तี & $\stackrel{20}{=}$ & $a$ & $\stackrel{m}{n}$ \\
\hline 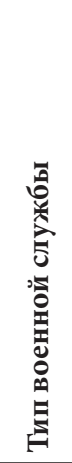 & 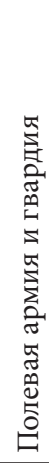 & 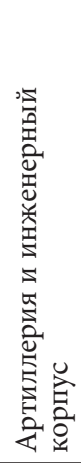 & 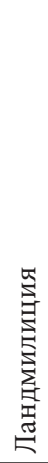 & 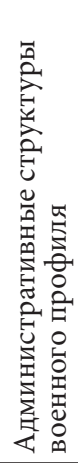 & 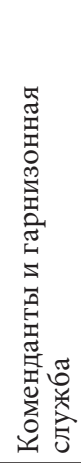 & 莺 & $\begin{array}{l}\stackrel{\circ}{0} \\
\stackrel{0}{S}\end{array}$ \\
\hline 은 $\frac{E}{z}$ & - & $N$ & $m$ & 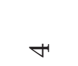 & in & 6 & \\
\hline
\end{tabular}


Как видим, эволюция генеральского корпуса отражала общие изменения в структуре сухопутных сил. Уже в первые годы после смерти Петра Великого была поставлена задача сокращения военных расходов и облегчения положения помещичьих крестьян, за счет подушной подати и рекрутской повинности с которых финансировалась и комплектовалась полевая армия. К проведению реформы правительство смогло приступить лишь после создания Воинской сухопутной комиссии 1730-1732 гг. Как известно, поставленные цели так и не были достигнуты. Вместе с тем общий рост военных расходов удалось сдержать, а незначительное сокращение полевой армии было компенсировано созданием более дешевых ландмилицких и гарнизонных частей [Петрухинцев, 2001, с. 71-73, 136-137, 139, 180184; Петрухинцев, 2014, с. 17-20, 205, 995]. Эту же тенденцию можно проследить в структуре генералитета: его доля и численность при полевой армии снижалась, а в частях и военных структурах, которые финансировались за счет иных источников (вне подушной подати), увеличивалась или оставалась неизменной.

В полевой армии с 27 мая 1728 г. вплоть до принятия воинского штата 1731 г. действовала петровская Табель 1720 г. со штатной численностью генералитета в 38 человек. По указу 31 мая 1731 г. (как и в 1726 г.) было принято решение о ликвидации бригадирских вакансий в армии и их сохранении в гарнизонных частях ${ }^{8}$. Аннинский штат был окончательно утвержден 28 октября 1731 г. и предусматривал наличие 26 представителей генералитета [ПСЗ-І, т. 43, ч. 1, отд. 1, с. 171-172, 177-178]. Жалованье русским и иноземцам предполагалось платить равное 9

Также изменились источники финансирования генералитета Низового корпуса. Со времени образования корпуса при Петре I полевые полки в Закавказье состояли «сверх табельного числа» и не входили в армейский штат. Но поскольку в полевой армии наблюдался постоянный некомплект офицеров и нижних чинов ${ }^{10}$, а часть военных находилась в «домовых отпусках», то по указу 13 ноября 1724 г. сэкономленные средства регулярно направлялись на жалованье сверхштатным генералам (включая Низовой корпус) [Сб. РИО, т. 56, с. 331-332, 334; т. 84, с. 154, 509; т. 101, с. 55, 256; РГАДА, ф. 248, кн. 437, л. 15, 172-174.]. С 1727 г. часть генералов, служивших в Персии (например, В. В. Долгоруков, В. Я. Левашов), помимо основного жалованья стали получать «прибавочные суммы» из «гилянских доходов» [Сб. РИО, т. 63, с. 8-9, 65-66, 134; РГАДА, ф. 248, кн. 437, л. 167 об.]. По указу 11 ноября 1731 г. в связи с принятием аннинского штата генералитет Низового корпуса был полностью исключен из окладной армейской суммы и переведен на доходы с персидских провинций [Сб. РИО, т. 101, с. 14, 402; РГАДА, ф. 248, кн. 437,

\footnotetext{
8 «Бригадирам при полевой армии впредь не быть, но при гарнизонном штате оной бригадирской чин оставляется» [ПСЗ-І, т. 43, ч. 1, отд. 1, с. 55-56].

${ }^{9}$ По резолюции императрицы от 14 июля 1731 г. [ПСЗ-І, т. 43, ч. 1, отд. 1, с. 165].

${ }^{10}$ Данные о некомплекте офицерского корпуса в 1725-1745 гг. см.: [Калашников, c. 49-50].
} 
л. 234, 253 об., 609; кн. 440, л. 2]. В это время при корпусе состояло шесть генералов: генерал-аншеф В. Я. Левашов, генерал-майоры П. де Бриньи, Е. И. Фаминцын, А. Б. Бутурлин, Д. Ф. Еропкин, а также отправленный к ним «в прибавку» генерал-лейтенант О.-Г. Дуглас [Сб. РИО, т. 104, с. 14-15]. После того как Низовой корпус был выведен из Персии в Россию (1732-1735 гг.), полки, включая генералитет, финансировались уже из Штатс-конторы ${ }^{11}$.

Сопоставим ежегодную численность полевого генералитета до и после принятия штата 1731 г. Показатели мирных 1725-1731 гг. (37-45 лиц $\left.{ }^{12}\right)$ были выше, чем в 1732-1736 гг. (30-34 лиц), и это с учетом, что с марта 1734 г. армия перешла на штаты военного времени [ПС3-I, т. 9, № 6472, с. 194]. Своей максимальной численности (42-43 человека) генералитет достиг только в 1737-1739 и 1741 гг. (второй период турецкой и начало шведской войны). Еще более наглядны следующие данные. Доля генералитета, состоявшего при полевой армии и гвардии, в общей массе армейских генералов 1725-1731 гг. составляла 52$63 \%$, а в 1732-1741 гг. снизилась до 41-45 \% (с колебаниями от $49 \%$ в 1737 г. до 35-39 \% в конце 1740 г.).

Отметим еще одну важную тенденцию - изменение национального состава командования. Так, в 1725 г. иноземцами являлись 35 \% генералов полевой армии, в 1726-1730 гг. - 42-45 \%, в 1730-1738 гг. 46-50 \%, а в 1739-1741 гг. более половины - 51-70\% ${ }^{13}$. Как видим, кадровая политика Анны Иоанновны во многом была продолжением курса прежних правительств, а влияние генералов-иноземцев стало укрепляться уже при Екатерине I и Петре II.

Артиллерия, инженерный корпус, ландмилиция, военная администрация, нерегулярные и гарнизонные части, в отличие от полевой армии, содержались не за счет подушной подати, а из других источников [Петрухинцев, 2001, с. 107-108]. Поэтому здесь прослеживаются иные тенденции.

Так, в артиллерийском и инженерном корпусе (по ежегодным данным) в 1725-1730 гг. служило от 9 до 12 генералов, а в 1730-1741 гг. уже 11-17. Доля этой группы в армейском генералитете незначительно выросла: с 12-16 до 14-22 \% соответственно. Всего в 1730-1741 гг. при артиллерийской и инженерной части числилось 25 генералов. Доля русских, как и раньше, была невелика (по ежегодным данным, от 0 до 23 \%).

Важным шагом аннинского царствования стало расширение ландмилиции - более дешевого (сравнительно с полевой армией) вида вооруженных сил, который комплектовался и содержался за счет однодворцев [Петрухинцев, 2001, с. 120-131; Петрухинцев, 2014, с. 227, 232; Байов, c. 17-19]. По инициативе Б.-Х. Миниха 19 марта 1736 г. был утвержден

${ }^{11}$ Судя по сенатским материалам, ежегодная переписка Военной коллегии о присылке из Штатс-конторы «сумм» на содержание выведенного Персидского корпуса продолжалась вплоть до 1742 г. [см.: РГАДА, ф. 248, кн. 440, л. 356, 357-358, 362, 424, 435-437 об., 439 об., 441, 444-445 об., 448-449 об.].

12 Показатель 1728 г. (52 человека) не характерен для этого периода.

${ }^{13}$ По данным Г. В. Калашникова, значительный рост иностранцев в армии после окончания русско-турецкой войны отмечался и среди офицеров [Калашников, с. 51-52]. 
особый штат Украинского ландмилицкого корпуса. При корпусе числилось 5 генералов, получавших жалованье из особой «ландмилицкой суммы». Если офицерские чины ландмилиции считались младше армейских, то генеральские рассматривались как равные [Сб. РИО, т. 104, с. 71; ПС3-І, т. 8, № 5903, с. 586-587; т. 43, ч. 1, отд. 1, с. 213-214, 217, 225-226, 229]. В общей сложности за весь период (1731-1741 гг.) при ландмилиции служило 14 человек (3-7 \% от общего числа армейских генералов; 2-6 человек ежегодно). Большинство из них - иноземцы.

Количество генералов в военных административных структурах также увеличилось. В 1725-1730 гг. их было 13-16, а в 1730-1741 гг. - уже 19-30 человек. В процентном выражении от общего числа армейских генералов эта группа в 1725-1727 гг. составляла 20-25 \%, в 1728-1730 гг. 17-21 \%, а в 1730-1741 гг. - 22-32 \%. Как и ранее, большая часть администраторов 1730-1741 гг. имела русское происхождение - 55-78 \%.

Теперь обратимся к руководству гарнизонных частей. По Табели 28 октября 1731 г. обер-комендантами и комендантами должны были стать 16 генералов (5 генерал-майоров и 11 бригадиров) ${ }^{14}$. Для сравнения:штат 17 августа 1725 г. предполагал 13 подобных вакансий (всебригадирские) [ПС3-I, т. 43, ч. 1, отд. 1, с.43-44]. В действительности в 17301741 гг. на комендантских должностях и в гарнизонных частях (по ежегодным данным) служило от 12 до 23 генералов (15-27 \% армейского генералитета). Национальный состав этой группы изменился. Если в 1725-1734 гг. большинство комендантов (53-74 \%) были русскими, то в 1735-1741 гг. их доля снизилась до 41-53 \%. В общей сложности за весь период (1730-1741 гг.) на комендантских должностях служило 52 генерала.

Интересны перемены и в последней - шестой - группе (в табл. 3 она обозначена как «другие»). В 1725-1730 гг. она составляла 2-6 \% от числа армейских генералов, а в 1730-1741 гг. - уже 8-15 \% (в абсолютном выражении 2-4 и 5-13 человек соответственно). Сюда отнесены генерал-адъютанты ЕИВ, кавалергарды (1730-1731 гг.), руководство смоленской шляхты. Все перечисленные подгруппы уже существовали в предшествующий период (1725-1730 гг.), но были не столь многочисленны. Новой подгруппой стал генералитет нерегулярных полков, созданных в период русско-турецкой войны. Так, при слободских полках служили бригадиры А. Дунин, А. Л. Лесовицкий, при гусарских полках - К. А. Кантемир (волошский полк), И. Стоянов (сербский), при войске Донском - И. М. Краснощеков, И. Фролов.

\section{Национальный состав генеральского корпуса}

По общим данным, в 1730-1741 гг. из 266 генералов 157 (59\%) были русскими, а 109 (41 \%) - иноземцами. Для сравнения, в 1725-1730 гг. доля иноземцев была ниже - $34 \%$.

14 Численность по Табели 28 октября 1731 г. [см.: ПС3-I, т. 43, ч. 1, отд. 1, с. 179]. По высочайше утвержденному мнению Сената от 14 июля 1731 г. - 5 генерал-майоров и 10 бригадиров [Там же, с. 68-71]. 
В динамике национальная структура генералитета выглядела следующим образом. В 1730-1738 гг. соотношение русских (60-63 \%) и иноземцев (37-40 \%) было стабильным. Те же показатели наблюдались в 1725-1730 гг. Следовательно, каких-либо резких перемен в кадровой политике после прихода к власти Анны Иоанновны не произошло. Рост иноземцев начался лишь десятилетие спустя: в 1739 г. $42 \%$, а в 1740-1741 гг. - 45-46 \%. Причина заключалась в отставке непропорционально большого числа русских генералов в $1738-1741$ гг. $^{15}$ Так, среди 28 человек, отправленных в это время в полную отставку, было 7 иноземцев (25\%) и 21 русский генерал (75\%).

\section{Генералы-иноземцы}

Проанализируем состав иноземцев подробнее. Для этого выделим пять групп в зависимости от времени начала службы и места рождения ${ }^{16}$.

В первую группу отнесены иноземцы «старого выезда» - те, кто родился в России или поступил на русскую службу до 1689 г., а также их потомки - 22 человека $(21 \%)^{17}$. Представители второй группы родились за рубежом и начали служить в России в 1689-1699 гг. 8 человек $(8 \%)^{18}$. Самая значительная - третья - группа генералов 1730-1741 гг. перешла на русскую службу в первой четверти XVIII в. 47 лиц $(45 \%)^{19}$. В 1725-1730 гг. (четвертая группа) на службу поступили

${ }^{15}$ Подробно практика чинопроизводства и отставок в российском генералитете 1730-1741 гг. будет рассмотрена в отдельной работе.

${ }_{16}$ Точное время поступления на службу неизвестно для трех человек: К.-Г. Левенвольде, Г.-А. и И.-Г. Менгдены (все из Прибалтики); для двух человек неизвестны время поступления на службу и место рождения: Демарин, М. И. Липхер.

17 Это Ф. Н. Балк, П. Ф. Балк-Полев, А. В. Беер, И. Л. и Л. Л. Блюментросты, А. Р. Брюс, Ф. Я. Буларт, И. Д. Бухгольц, П. А. Гассениус, А. П. Девиц, В. В. Делдин, Н. Л. Клячковский, Ю. Ф. Лесли, А. Я. Лицкин, Т. И. и Я. М. Трейдены, Е. И. Фаминцын, В. Ю. и В. В. Ферморы, И. Шван, А. Т. Юнгер, В. В. Якоби. Об особенностях группировки иноземцев на «старый» и «новый выезд» см.: [Черников, 2013а, с. 136].

18 Это уроженцы Германии (5) - М. М. Витвер (1697), Г. Гейн (1698), Г.-В. Геннин (1697), И. И. Кобер (1696), Л. Л. Шток (1696); Швейцарии (1) - П. Б. Лефорт (1694), Швеции (1) - У. О. Сперрейтер (1694), Польщи (1) - П. И. Ягужинский.

19 Это выходцы из Германии (17) - И. И. Альбрехт (1706), Г.-И. Бон (1708), И.-Б. Вейсбах (1707), Т.-Г. Венедиер (1707), И.-Г. Гарбер (1710), Л. И. Гартунг (1713), Х.-Л. Гейденрейх (1707), Л.-Г. Гессен-Гомбургский (1723), К. И. Гохмут (1704), Х.-Т. Киндерман (1715), И.-Л. Люберас (1709), Э.-С. Манштейн (1704), Б.-Х. Миних (1721), Б.-Х. Фридерици (1716), Ф. Центаров (1710), Ф. И. Штофель (1708), Э.-И. Эйлерс (1703); Прибалтики (11) - К. Бирон, В. Бриммер (1708), Х.-В. Виттен (1718), И.-Х. Кейзерлинг (1717), Ф. Левен, Ю. Г. Ливен (1717), Г.-Г. Розен (1703), О.-Ф. Розен (1704), И.-Г. Ропп, Б.-Э. Траутфеттер (1724), В.-Г. Фелькерзам (1710); Франциии (5) - А. и П. де Бриньи (оба 1717), И. Я. Дюпре (1703), А. Клапье де Колонг (1712), А. Кулон (1707); Польши (2) - Б. И. Незабитовский (1719), Х. Урбанович (1724); Швециии (2) - О.-Г. Дуглас (1717), И.-Б. Кампенгаузен (1711); Италии и Адриатического региона (2) - А. де Брильи (1701), И. Стоянов (1723); Голландии (1) - А. И. Брунц (1702); Ирландии (1) - П. П. Ласси (1700); Швейиарии (1) А. Я. Трезини (1703); Грузии (1) - Г. Л. Дадиани (не позднее 1718). Точное место рождения неизвестно еще для четырех человек - А. Беренса (1702), И. Гампфа (1707), А. А. Поникау (1716), М. Фукса. 
6 генералов $(6 \%)^{20}$. Непосредственно в 1730-1741 гг. (пятая группа) на службу был принят 21 генерал $(20 \%)^{21}$.

Сравним эти данные с показателями предшествующего периода. Доля генералов, поступивших на службу в первой четверти XVIII в., почти не изменилась: в 1725-1730 гг. - 49 \%, а в 1730-1741 гг. - $45 \%$. То же самое можно сказать об иноземцах «старого выезда» - 24 и $21 \%$. Напротив, доля тех, кто служил в России с 1689-1699 гг., существенно сократилась - 20 и 8 \% соответственно.

Обобщим данные за 1689-1741 гг. (2-5 группы). В составе генералитета 1725-1730 гг. было 19 уроженцев Германии (45 \%). В 1730-1741 гг. немцы сохранили свое лидирующее положение (34 человека, 43 \%). Число остзейцев резко выросло: в 1725-1730 гг. их было четверо (10\%), а в 1730-1741 гг. - уже 22 человека (28 \%). Половина остзейцев (11 из 22) поступили на русскую службу еще при Петре Великом. Суммарно Германия и Прибалтика дали более $2 / 3$ иностранцев в российском генералитете 1730-1741 гг. Представителей остальных регионов было существенно меньше: пять генералов из Франции (6 \%), четыре - из Польши (5 \%), по три - из Ирландии и Швеции (по 4 \%), по два - из Грузии, Италии и Адриатики, Швейцарии (3\%), по одному - из Шотландии, Молдавии и Голландии (по 1 \%). Подавляющее большинство генералов, приехавших в Россию в 1730-1741 гг., имели военный опыт и ранее служили в европейских армиях ${ }^{22}$.

Как генералы-иноземцы распределялись по видам службы (в зависимости от времени ее начала)? Самые существенные изменения произошли в полевой армии. Так, в генералитете 1725-1730 гг. около 60 \% иноземцев начинали свою службу в 1700-1725 гг. При Анне Иоанновне и Иоанне Антоновиче доля генералитета «петровского призыва» 1700-1725 гг. снизилась до 42 \%, а значительную часть командования полевой армии составили генералы, принятые на службу непосредственно в 1730-1741 гг. (27\%). В ландмилиции доля «новичков» была еще выше - 44 \% («петровский призыв» - 22 \%). В остальных видах вооруженных сил ситуация была схожа с предшествующим периодом. Так, среди артиллеристов и инженеров 78 \% иноземцев служили

20 Это уроженцы Германии (2) - Г.-Н. Брадке (1729), Ф.-Б. Шверин (1727); Грузии (1) - Б. В. Грузинский (1729); Польши (1) - Ф. Даревский (1726); Прибалтики (1) Г.-Ю. Икскюль (1729); Шотландии (1) - Д. Кейт (1728).

21 Это выходцы из Германии (10) - Л.-А. Бисмарк (1732), А.-У. Брауншвейгский (1733), Р. К. Вейдель (1731), Г.-К. Вейсбах (1736), П.-А. Голштейн-бек (1734), У.-Ф. Левендаль (1736), А.-Ф. Теттау (1730), И.-Б. Фишер (1734), К.-Л. Шпигель (1732), Г.-А. Штокман (1732); Прибалтики (7) - Г. Бирон (1730), К.-М. Бирон (1732?), П. Бирон (1733), Э.-И. Бутлер (1735), Б.-Х. Вильдеман (1732), О.-И. Майдель (1736), Ю.-Г. Радинг (1736); Ирландии (2) - Ю. Ю. Броун (1731), Г. П. Ласси (1731); Молдавии и Валахии (1) К. А. Кантемир (1738). Неизвестно место рождения одного человека - Декаласа (1738).

${ }^{22}$ Так, например, Л.-А. Бисмарк служил в Пруссии, П.-А. Голштейн-бек - в Пруссии и Гессен-Касселе, У.-Ф. Левендаль - в Польше, Саксонии, Дании, Австрии и Генуе, А.-Ф. Теттау - в Пруссии и Гессен-Касселе, К.-Л. Шпигель - в Гессен-Касселе и ГессенДармштадте, Г.-А. Штокман - в Ганновере, Голштейне и Швеции, Г. Бирон - в Польше, К.-М. Бирон и Э.-И. Бутлер - в Польше и Саксонии, О.-И. Майдель - в Швеции, Ю.-Г. Радинг - в Голландии, Пфальце и Гессен-Касселе, Ю. Ю. Броун - в Пфальце, Р. К. Вейдель - в Испании, Г.-К. Вейсбах - в Польше, Декалас - в Австрии. 
в России с 1689-1725 гг. (хотя доля поступивших на службу после 1700 г. существенно увеличилась). В военной администрации «петровские иноземцы» также доминировали (61 \% генералов служили с 1700-1725 гг.). В гарнизонной службе 52 \% иноземцев были старовыезжими, а 38 \% прибыли в Россию в 1700-1725 гг. Таким образом, пополнение генералитета 1730-1741 гг. новыми людьми из-за рубежа затрагивало в первую очередь полевую армию и ландмилицию. Ротация высшего командного состава в артиллерии, инженерном корпусе, военной администрации и гарнизонных частях в основном происходила за счет «внутренних резервов» - повышения в чинах тех, кто уже находился на русской службе.

Национальная структура иноземного генералитета (сравнительно с 1725-1730 гг.) изменилась менее значительно. В полевой армии 38 \% иноземцев были уроженцами Германии (в 1725-1730 гг. - 34 \%), при артиллерии и в инженерном деле - 56 \% (54\%), в военной администрации - 52 \% (58 \%), при ландмилиции - 56 \%. В гарнизонных частях немцев было лишь $14 \%$ (22 \%). Остзейцы в основном служили при полевой армии - 23 \% (в 1725-1730 гг. - 10 \%) и в ландмилиции $22 \%$. Французы проходили службу артиллеристами и инженерами (22\%), в военной администрации (13\%) или в гарнизонных частях (14\%). Иноземцы «старого выезда» преобладали среди комендантов (52\%), а в полевой армии они были третьими по численности (15\%), уступая лишь немцам и остзейцам.

\section{Генералитет русского происхождения}

Теперь обратимся к русской части генералитета - 157 человек из 128 фамилий. Подавляющее большинство генералов начинали свою службу при Петре I или в более раннее время. Лишь трое поступили на службу после 1725 г.: В. А. Лопухин, Н. И. и П. И. Стрешневы (все в 1727 г.) $)^{23}$. Выделим среди русских генералов четыре группы в зависимости от происхождения ${ }^{24}$. К первой (аристократической) отнесены 22 лица из 12 родов $^{25}$. Во вторую группу включены фамилии, представители которых вошли в Думу в 1613-1689 гг. (34 лица из 24 родов $\left.^{26}\right)$. В третью группу вошли фамилии московского дворян-

${ }^{23}$ Неизвестно время начала службы еще для трех человек: А. Дунина, И. Фролова, И. А. Шипова.

${ }^{24}$ Общие принципы классификации см.: [Черников, 2007, с. 373-379].

${ }^{25}$ А. Б. и П. И. Бутурлины, А. П. и И. М. Волынские, кн. М. М. старший Голицын, И. М. Головин, кн. В. В. Долгоруков, кн. В. А. и Ю. А. Репнины, В. Ф., В. С., П. С. и С. А. Салтыковы, кн. И. Ю., Н. Ю. и Ю. Ю. Трубецкие, кн. В. А. и Г. А. Урусовы, кн. П. Б. Черкасский, В. П. Шереметев, кн. М. Ю. и О. И. Щербатовы.

${ }^{26}$ А. М. и С. Ф. Апраксины, кн. А. Т., И. Ф. и М. М. Барятинские, Д. Ф. Еропкин, А. К. Зыков, И. П., Л. В. и П. В. Измайловы, И. С. и С. Ю. Карауловы, М. И. Леонтьев, В. А. и Ф. А. Лопухины, М. А. Матюшкин, С. Г. Нарышкин, Д. И. Павлов, А. И. и И. В. Панины, Ф. А. Полибин, А. М. Потемкин, П. К. Пушкин, В. М. Ртищев, Н. И. и П. И. Стрешневы, С. И. Сукин, М. А. Сухотин, Д. И. Титов, С. Т. Хлопов, М. С. Хрущев, кн. А. И. Шаховской, Д. А. и Ф. А. Шепелевы. 
ства, не достигшие к 1689 г. думных чинов (94 человека из 85 фамилий $\left.{ }^{27}\right)$. К четвертой группе отнесены недворяне (7 человек из 7 фамилий ${ }^{28}$. Наибольшее представительство в генералитете имели Салтыковы (4 человека), а также Измайловы, кн. Трубецкие, кн. Барятинские, Козловы (по 3 человека).

Динамика социальной структуры русского генералитета отражена в табл. 4.

Таблиияа 4

Происхождение русской части генералитета 1730-1741, лиц (\%)

\begin{tabular}{|c|c|c|c|c|c|c|c|c|c|c|c|c|c|c|}
\hline Группа & 1730 & 1731 & 1732 & 1733 & 1734 & 1735 & 1736 & 1737 & 1738 & 1739 & 1740A & $1740 \mathrm{~B}$ & 1740АЛ & 1741 \\
\hline I & $\begin{array}{c}14 \\
(19)\end{array}$ & $\begin{array}{c}11 \\
(15)\end{array}$ & $\begin{array}{c}11 \\
(17)\end{array}$ & $\begin{array}{c}11 \\
(17)\end{array}$ & $\begin{array}{c}11 \\
(17)\end{array}$ & $\begin{array}{c}12 \\
(18)\end{array}$ & $\begin{array}{c}12 \\
(16)\end{array}$ & $\begin{array}{c}12 \\
(17)\end{array}$ & $\begin{array}{c}12 \\
(16)\end{array}$ & $\begin{array}{c}11 \\
(15)\end{array}$ & $9(13)$ & $8(13)$ & $\begin{array}{c}8 \\
(13)\end{array}$ & $\begin{array}{c}10 \\
(14)\end{array}$ \\
\hline II & $\begin{array}{c}18 \\
(24)\end{array}$ & $\begin{array}{c}18 \\
(25)\end{array}$ & $\begin{array}{c}17 \\
(26)\end{array}$ & $\begin{array}{c}18 \\
(29)\end{array}$ & $\begin{array}{c}20 \\
(30)\end{array}$ & $\begin{array}{c}19 \\
(28)\end{array}$ & $\begin{array}{c}17 \\
(23)\end{array}$ & $\begin{array}{c}16 \\
(23)\end{array}$ & $\begin{array}{c}17 \\
(23)\end{array}$ & $\begin{array}{c}16 \\
(22)\end{array}$ & $\begin{array}{c}15 \\
(22)\end{array}$ & $\begin{array}{c}14 \\
(23)\end{array}$ & $\begin{array}{c}13 \\
\text { (21) }\end{array}$ & $\begin{array}{c}14 \\
(20)\end{array}$ \\
\hline III & $\begin{array}{c}41 \\
(55)\end{array}$ & $\begin{array}{c}43 \\
(60)\end{array}$ & $\begin{array}{c}37 \\
(57)\end{array}$ & $\begin{array}{c}34 \\
(54)\end{array}$ & $\begin{array}{c}34 \\
(52)\end{array}$ & $\begin{array}{c}36 \\
(53)\end{array}$ & \begin{tabular}{|c}
43 \\
$(59)$
\end{tabular} & $\begin{array}{c}41 \\
(59)\end{array}$ & $\begin{array}{c}42 \\
(57)\end{array}$ & $\begin{array}{c}42 \\
(58)\end{array}$ & $\begin{array}{c}41 \\
(59)\end{array}$ & $\begin{array}{c}35 \\
(56)\end{array}$ & $\begin{array}{c}35 \\
(57)\end{array}$ & $\begin{array}{c}42 \\
(59)\end{array}$ \\
\hline IV & $\begin{array}{c}1 \\
\text { (1) }\end{array}$ & $\begin{array}{c}0 \\
(0)\end{array}$ & $\begin{array}{c}0 \\
(0)\end{array}$ & $\begin{array}{c}0 \\
(0)\end{array}$ & $\begin{array}{c}1 \\
\text { (2) }\end{array}$ & $\begin{array}{c}1 \\
\text { (1) }\end{array}$ & $\begin{array}{c}1 \\
(1)\end{array}$ & $\begin{array}{c}1 \\
\text { (1) }\end{array}$ & \begin{tabular}{|c}
3 \\
$(4)$
\end{tabular} & $\begin{array}{c}4 \\
(5)\end{array}$ & $\begin{array}{c}4 \\
(6)\end{array}$ & $\begin{array}{c}5 \\
(8)\end{array}$ & $\begin{array}{c}5 \\
(8)\end{array}$ & $\begin{array}{c}5 \\
\text { (7) }\end{array}$ \\
\hline I-IV & 74 & 72 & 65 & 63 & 66 & 68 & 73 & 70 & 74 & 73 & 69 & 62 & 61 & 71 \\
\hline I-II & $\begin{array}{c}32 \\
(43)\end{array}$ & $\begin{array}{c}29 \\
(40)\end{array}$ & $\begin{array}{c}28 \\
(43)\end{array}$ & $\begin{array}{c}29 \\
(46)\end{array}$ & $\begin{array}{c}31 \\
(47)\end{array}$ & $\begin{array}{c}31 \\
(46)\end{array}$ & $\begin{array}{c}29 \\
(40)\end{array}$ & $\begin{array}{c}28 \\
(40)\end{array}$ & $\begin{array}{c}29 \\
(39)\end{array}$ & $\begin{array}{c}27 \\
(37)\end{array}$ & $\begin{array}{c}24 \\
(35)\end{array}$ & $\begin{array}{c}22 \\
(35)\end{array}$ & $\begin{array}{c}21 \\
(34)\end{array}$ & $\begin{array}{c}24 \\
(34)\end{array}$ \\
\hline
\end{tabular}

Как видим, представительство «думных фамилий» (I-II группы) продолжало снижаться. В 1729-1730 гг. удельный вес традиционной элиты составлял 43-44 \%, а в 1740-1741 гг. - уже 34-35 \%. Кратковременный рост показателей наблюдался лишь в 1733-1735 гг. (4647 \%). Интересно, что доля московского дворянства за 1730-1741 гг.

${ }^{27}$ П. Д. Аксаков, В. С. Аракчеев, А. П. Арсеньев, И. И. Бахметев, И. Г. Безобразов, И. И. Бибиков, И. В. Болтин, В. С. Борзово, А. А. Броневский, С. С. Буженинов, П. П. Воейков, М. Я. Волков, И. М. Вырубов, кн. В. М. Вяземский, Д. Г. Голенищев-Кутузов, И. М. и С. Т. Грековы, П. В. Григоров, В. М. Гурьев, И. И. Дмитриев-Мамонов, С. Н. Друмант (его отцом был рейтарский полковник Н. П. Друмант, крестившийся в православие и пожалованный в чины стряпчего, а затем стольника), А. Н. Дубасов, А. Н. и Ф.Н.Елагины, Г. Д.Есипов, А. С. Жилин, А. Г.Загряжский, В.И. Заезерский, П. И. Засецкий, И. И. Захаров, С. Л. Игнатьев, И. К. Ильин, И. Г. Карташов, А. Г. Киселев, А. С. Козинский, И. Ф., Н. А. и Ф. И. Козловы, И. Л. Кокошкин, П. М. Колокольцов, Т. А. Коробов, Р. М. Кошелев, Н. С. Кречетников, Кн. Я. Н. Кропоткин, И. И. Кропотов, Н. Н. Кудрявцев, П. И. Лачинов, В. Я. Левашов, А. Д. Лукин, Я. К. Лярский, И. А. Маслов, кн. С. Ф. Мещерский, М. О. Молчанов, П. И. Мошков, А. А. Мякинин, Г. Я. и Ф. В. Наумовы, В. В. Нейбуш («из дворян»; его отец выехал из Пруссии, принял православие и служил полковником при Алексее Михайловиче), А. И. Немцов, Д. Ю. и М. С. Опочинины, Я. Г. Островский, Е. И. Пашков, А. К. Петров-Солово, Д. Л. Порецкий, В. И. Порошин, А. И. и Н. И. Румянцевы, И. Т. Сафонов, П. Г. Свечин, С. В. Секиотов, У. А. Сенявин, Б. Г. СкорняковПисарев, Л. Я. Соймонов, И. В. Стрекалов, А. М. Сухарев, А. И. Тараканов, И. М. Тургенев, И. С. Унковский, А. И. Ушаков, И. А. Фамендин, М. И. Философов, П. В. Чебышев, Ф. Г. Чекин, Д. Г. Чернцов, А. И. и Г. П. Чернышевы, А. Г. Шамордин, Т. А. Шатилов, И. А. и П. М. Шиповы, И. М. Шувалов, И. Ф. Юрлов, кн. Г. Д. Юсупов.

${ }^{28}$ С. А. Алабердеев, А. Дунин, И. М. Краснощеков, А. Л. Лесовицкий, И. С. Савельев, А. Ф. Томилов, И. Фролов. 
практически не изменилась: 55-60 \% в начале и 56-59 \% в конце периода. В течение же предшествующих 30 лет она неуклонно росла: в 1700-1701 гг. - 11-20\%, в 1724-1725 гг. - 45-46 \%, в 1729-1730 гг. 54-56 \%. Новым явлением для 1730-х гг. стало увеличение числа недворян в генералитете (к 1740-1741 гг. - 6-8 \%). Более половины из них - представители казачества, которые командовали нерегулярными армейскими частями.

По моим подсчетам, 66 \% русского генералитета 1725-1730 гг. (73 человека) начинали свою карьеру в думных или московских чинах. В 1730-1741 гг. их доля значительно снизилась - 45 \% (70 человек). По ежегодным данным, обладатели старых чинов в 1725 г. составляли 76 \% русского генералитета, в 1730 г. - 60-61 \%, в 1739 г. - 44 \%, а в 1740-1741 гг. (из-за массовых отставок) этот показатель резко упал до 27-30 \%. В первой половине елизаветинского царствования с политической сцены сойдут последние представители этого слоя.

\section{Чиновная структура генеральского корпуса}

Рассмотрим состав генералитета по классам Табели о рангах (табл. 5).

Таблица 5

Структура генералитета 1730-1741 гг. по классам Табели о рангах, лиц

\begin{tabular}{|c|c|c|c|c|c|c|c|c|c|c|c|c|c|c|}
\hline Класс & 1730 & 1731 & 1732 & 1733 & 1734 & 1735 & 1736 & 1737 & 1738 & 1739 & $1740 \mathrm{~A}$ & $1740 \mathrm{5}$ & 1740АЛ & 1741 \\
\hline 1 & 3 & 2 & 2 & 2 & 2 & 2 & 3 & 3 & 3 & 3 & 2 & 2 & 3 & 3 \\
\hline 2 & 13 & 11 & 8 & 8 & 8 & 9 & 8 & 7 & 8 & 8 & 12 & 10 & 7 & 10 \\
\hline 3 & 20 & 18 & 18 & 18 & 21 & 21 & 20 & 22 & 20 & 19 & 19 & 20 & 21 & 25 \\
\hline 4 & 44 & 45 & 41 & 40 & 38 & 37 & 39 & 40 & 40 & 41 & 45 & 44 & 45 & 48 \\
\hline 5 & 40 & 42 & 39 & 36 & 41 & 44 & 45 & 43 & 51 & 55 & 48 & 39 & 35 & 43 \\
\hline Итого & 120 & 118 & 108 & 104 & 110 & 113 & 115 & 115 & 122 & 126 & 126 & 115 & 111 & 129 \\
\hline
\end{tabular}

Если в течение года (периода) какое-либо лицо последовательно или одновременно носило несколько чинов разного ранга, то при подсчетах учитывался старший.

В 1730-1741 гг. высшие армейские чины (генерал-фельдмаршала и генералиссимуса) носили шесть человек: трое русских и трое иноземцев. Если аннинское царствование начиналось с доминирования на военном олимпе русских фельдмаршалов (все трое - аристократы), то с 1736 г. большинство в этом ранге составляли иностранцы.

Во втором классе в 1730-1741 гг. в общей сложности служило 26 лиц. На протяжении почти всего этого периода (1730-1738 гг., конец 1740-1741 гг.) здесь преобладали русские. По сравнению с 1725-1730 гг. 
социальный состав генерал-аншефов стал более пестрым. Наряду с традиционной элитой (I-II группы) здесь служили выходцы из московского дворянства (М. Я. Волков, И. И. Дмитриев-Мамонов, В. Я. Левашов, А. И. Румянцев, А. И. Ушаков, Г. П. Чернышев, Г. Д. Юсупов). Если при Екатерине I и Петре II московское дворянство не поднималось по карьерной лестнице выше генерал-лейтенанта, то при Анне Иоанновне из этой среды происходила уже половина русских генераланшефов (7 из 14), а по ежегодным данным - 50-80 \%. Особенно высокой доля московских дворян была в 1739-1741 гг. - 71-80 \%.

В ранге генерал-лейтенанта в 1730-1741 гг. служило 64 человека (38 русских и 26 иноземцев), генерал-майора - 127 (62 русских и 65 иноземцев), бригадира - 137 (95 русских, 42 иноземца).

Обобщим сказанное. Период адаптации российской элиты к чиновной структуре Табели о рангах в начале правления Анны Иоанновны завершился, а расширение генеральского корпуса, которое наблюдалось в предшествующие пять лет, прекратилось. После принятия армейского штата 1731 г. численность генералитета уже напрямую зависела от того, вела ли армия боевые действия, а его структура отражала общие изменения в вооруженных силах. Так, доля генералов при полевой армии снизилась; в артиллерии же, инженерном корпусе, ландмилиции и в гарнизонных частях такой тенденции не наблюдалось.

В национальном составе генералитета резких изменений после восшествия на престол Анны Иоанновны не произошло (60-63 \% русских и 37-40 \% иноземцев). Лишь в самом конце периода (17391741 гг.) из-за массовых отставок русских генералов выросла доля иноземцев.

В полевой армии неуклонный рост числа иноземцев, начавшийся в 1725-1730 гг., продолжился, а к 1739-1741 гг. их доля составила 5170 \%. В артиллерии, инженерном корпусе, как и ранее, доминировали иноземные генералы, а в военной администрации - русские. Командование ландмилиции в основном состояло из иноземцев. Основой иноземного генералитета оставались выходцы из Германии. Важнейшим процессом в 1730-1741 гг. стала начавшаяся еще при Петре Великом инкорпорация представителей прибалтийского дворянства в состав российской элиты, а доля остзейцев в генералитете при Анне Иоанновне выросла с 10 до 28 \%. Таким образом, влияние уроженцев протестантских регионов на европеизацию российской армии оставалось решающим. Иностранные генералы, поступившие на службу в 17301741 гг., чаще всего направлялись в полевую армию и ландмилицию.

Динамика социальной структуры русской части генералитета была прежней. Доля традиционной элиты снижалась, а представители московского дворянства достигли чина генерал-аншефа, составив в нем большинство. Аристократическим остался лишь старший, фельдмаршальский класс. 
В целом эволюция генеральского корпуса 1730-1741 гг. подчинялась общей логике развития вооруженных сил России, заложенной еще при Петре Великом, а перемены начала аннинского царствования во многом стали следствием того внутриполитического курса, который был сформулирован ближайшим окружением царя-реформатора в 1725-1727 гг. Интернациональный состав российского генералитета 1730-1741 гг., его пополнение иностранцами и выходцами из присоединенного в начале века остзейского региона отражали установки петровского времени на заимствование европейского военного опыта.

\section{Список литературы}

Анисимов Е. В. Россия без Петра: 1725-1740. СПб. : Лениздат, 1994. 496 с.

Байов A. K. Русская армия в царствование императрицы Анны Иоанновны. Т. 1. СПб. : Тип. Н. Я. Стойковой, 1906. 556+192 с.

СА - Сенатский архив. Т. 2-5 : [Журналы и определения Правительствующего Сената за 1732, 1735, 1737-1743 гг.]. СПб. : Тип. Прав. Сената, 1889-1892.

Калашников Г. В. Офицерский корпус русской армии в 1725-1745 гг.: дис. ... к. и. н. СПб., 1999. 295 с.

Каменский А. Б. От Петра I до Павла I. Реформы в России XVIII века: опыт целостного анализа. М. : Изд-во РГГУ, 1999. 575 с.

Курукин И. В. Эпоха «дворских бурь» : Очерки истории послепетровской России, 1725-1762 гг. Рязань : НРИИД, 2003. 570 с.

Петрухинцев Н. Н. Внутренняя политика Анны Иоанновны (1730-1740). М. : РОССПЭН, 2014. $1063 \mathrm{c.}$

Петрухинцев $H . \quad H$. Царствование Анны Иоанновны: формирование внутриполитического курса и судьбы армии и флота, 1730-1735 г. СПб. : Алетейя, 2001. $352 \mathrm{c}$.

ПСЗ-І - Полное собрание законов Российской империи. Собрание первое. СПб. : Тип. ІІ отд. С.Е.И.В.К., 1830.

Рабинович М. Д. Социальное происхождение и имущественное положение офицеров регулярной русской армии в конце Северной войны // Россия в период реформ Петра I. М. : Наука, 1973. С. 133-171.

РГАДА - Российский государственный архив древних актов. Ф. 16 (Разряд XVI : Внутреннее управление); Ф. 20 (Разряд XX : Дела военные); Ф. 188 (Рукописное собрание ЦГАДА); Ф. 199 (Портфели Г.-Ф. Миллера); Ф. 210 (Разрядный приказ); Ф. 248 (Сенат и его учреждения); Ф. 286 (Герольдмейстерская контора); Ф. 350 (Ландратские книги и ревизские сказки).

РГВИА - Российский государственный военно-исторический архив. Ф. 489 (Формулярные списки); Ф. 490 (Офицерские сказки); Ф. 846 (Коллекция Военноученого архива).

Сб. РИО - Сборник императорского русского исторического общества. T. 104, 106, 108, 111, 114, 117, 120, 124, 126, 130, 138, 146 : [Бумаги Кабинета министров императрицы Анны Иоанновны, 1731-1740 гг.]. Юрьев : Тип. К. Маттисена, 1898-1915 ; Т. 55, 56, 63, 69, 79, 84, 94, 101 : [Протоколы, журналы и указы Верховного тайного совета, 1726-1730 гг.]. СПб. : Тип. И. Н. Скороходова, 1886-1898.

Черников C. В. «На убылые места... выбирать обществом»: к вопросу о причинах «шляхетского движения» начала 1730 г. // Cahiers du Monde russe. 2014a. Vol. 55. № 1-2. P. 71-117.

Черников С. В. Правящая элита России 1725-1730 годов: численность, социальный состав, основные тенденции развития // Вестник Челябинского гос. ун-та. 2014b. № 12. C. 30-38.

Черников С. В. Российская элита эпохи реформ Петра Великого: состав и социальная структура // Государство и общество в России XV - начала XX века. СПб. : Наука, 2007. С. 366-386. 
Черников С. В. Российский генералитет 1725-1730 гг.: численность, национальный и социальный состав // Quaestio Rossica. 2013a. № 1. С. 128-143.

Черников С. В. Чины государева двора в составе правящей элиты 1725-1730 гг. // Русь, Россия: Средневековье и Новое время. Вып. 3. М. : Изд-во МГУ, 2013b. С. 226231.

\section{References}

Anisimov, E. V. (1994). Rossiya bez Petra: 1725-1740 [Russia without Peter: 17251740]. Saint Petersburg: Lenizdat.

Bajov, A. K. (1906). Russkaya armiya v carstvovanie imperatricy' Anny' Ioannovny' [The Russian army during the reign of Empress Anna Ioannovna]. (Vol. 1). Saint Petersburg.

Chernikov, S. V. (2014). «Na uby'ly'e mesta... vy'birat' obshhestvom»: k voprosu o prichinah «shlyahetskogo dvizheniya» nachala $1730 \mathrm{~g}$. [«Na uby'ly'e mesta... vy'birat' obshhestvom»: on the issue of reasons for the noble movement of the early 1730s]. Cahiers du Monde russe, 55, 1-2, 71-117.

Chernikov, S. V. (2014). Pravyashhaya e'lita Rossii 1725-1730 godov: chislennost', social'ny'j sostav, osnovny'e tendencii razvitiya [The ruling elite of Russia in 1725-1730: population, social structure, the main development trends]. Vestnik Chelyabinskogo gosudarstvennogo universiteta, 12, 30-38.

Chernikov, S. V. (2007). Rossijskaya e'lita e'pohi reform Petra Velikogo: sostav i social'naya struktura [The Russian elite of the period of reforms of Peter the Great: personnel and social structure]. In Gosudarstvo i obshhestvo v Rossii XV-nachala XX veka (pp. 366-386). Saint Petersburg: Nauka.

Chernikov, S. V. (2013a). Rossijskij generalitet 1725-1730 gg.: chislennost', nacional'ny'j i social'ny'j sostav [The Russian General Staff in 1725-1730: Personnel, Ethnic and Social Structure]. Quaestio Rossica, 1, 128-143.

Chernikov, S. V. (2013b). Chiny' gosudareva dvora v sostave pravyashhej e'lity' 17251730 gg. [Ranks of the Tsar's court in the structure of the ruling elite, 1725-1730]. In Rus', Rossiya: Srednevekov'e i Novoe vremya (Iss. 3, pp. 226-231). Moscow.

Kalashnikov, G. V. (1999). Oficerskij korpus russkoj armii v 1725-1745 gg.: diss. ... kand. ist. nauk [The officer corps of the Russian army in 1725-1745]. (Dissertation). Saint Petersburg.

Kamenskij, A. B. (1999). Ot Petra I do Pavla I. Reformy'v Rossii XVIII veka: opy't celostnogo analiza [From Peter to Paul I. Reform in $18^{\text {th }} \mathrm{c}$. Russia: the experience of holistic analysis]. Moscow.

Kurukin, I. V. (2003). E'poha «dvorskih bur'» : Ocherki istorii poslepetrovskoj Rossii, 1725-1762 gg. [The era of "Court storms": essays on the Russian history after Peter I, 1725-1762]. Ryazan.

Petruhincev, N. N. (2014). Vnutrennyaya politika Anny' Ioannovny' (1730-1740) [Internal policy of Anna Ioannovna (1730-1740)]. Moscow: ROSSPE'N.

Petruhincev, N. N. (2001). Carstvovanie Anny' Ioannovny': formirovanie vnutripoliticheskogo kursa $i$ sud'by' armii i flota, 1730-1735 g. [The reign of Anna Ioannovna: shaping the internal policy and the fate of the army and Navy, 1730-1735]. Saint Petersburg: Aletejya.

Polnoe sobranie zakonov Rossijskoj imperii. Sobranie 1. [Complete Collection of Laws of the Russian Empire. Collection 1]. (1830). Saint Petersburg.

Rabinovich, M. D. (1973). Social'noe proishozhdenie i imushhestvennoe polozhenie oficerov regulyarnoj russkoj armii v konce Severnoj vojny' [Social origin and property status of officers of the regular Russian army at the end of the Great Northern War]. In Rossiya $v$ period reform Petra I (pp. 133-171). Moscow: Nauka.

Rossijskij gosudarstvenny'j arhiv drevnih aktov [Russian state archive of old acts]. Stocks 16, 20, 188, 199, 210, 248, 286, 350.

Rossijskij gosudarstvenny'j voenno-istoricheskij arhiv, St. Peterburg. [Russian state military-historical archive]. Stocks 489, 490, 846.

Senatskij arhiv: Zhurnaly'i opredeleniya Pravitel'stvuyushhego Senata za 1732, 1735, 1737-1743 gg. [Senate archive: Magazines and ruling of the directing Senate in 1732, 1735, 1737-1743 yrs]. (Vol. 2-5). (1889-1892). Saint Petersburg.

Sbornik imperatorskogo russkogo istoricheskogo obshhestva. Bumagi Kabineta ministrov imperatricy' Anny' Ioannovny', 1731-1740 gg. [Papers of the Cabinet of Ministers of the 
Empress Anna Ioannovna, 1731-1740]. (1898-1915). (Vols. 104, 106, 108, 111, 114, 117 , 120, 124, 126, 130, 138, 146). Yuriev.

Sbornik imperatorskogo russkogo istoricheskogo obshhestva. Protokoly', zhurnaly' $i$ ukazy' Verhovnogo tajnogo soveta, 1726-1730 gg. [Protocols, magazines and decrees of the Supreme privy Council, 1726-1730]. (1886-1898). (Vols. 55, 56, 63, 69, 79, 84, 94, 101). Saint Petersburg.

The article was submitted on 15.01.2015

Сергей Васильевич Черников, к. и. н., доцент,

Липецкий государственный технический университет, Липецк, Россия zserg72@gmail.com
Sergey Chernikov, Dr., Associate Professor, Lipetsk State Technical University, Lipetsk, Russia zserg72@gmail.com 